\title{
Evaluating Metabolic Responses in Mice to Nanosized Titanium Dioxide Particles Using Gas Chromatography- Mass Spectrometry Based Metabolomics
}

\author{
Singh $\mathrm{AK}^{1,2, \$}$, Ratnasekhar $\mathrm{Ch}^{1, \$}$, Chaudhari BP ${ }^{3}$, \\ Singh D ${ }^{4}$, Chattopadhyay BD ${ }^{2}$, Mudiam MKR ${ }^{5 *}$ \\ ${ }^{1}$ Analytical Chemistry Laboratory, Regulatory Toxicology \\ Group, CSIR-Indian Institute of Toxicology Research, \\ Lucknow, India \\ ${ }^{2}$ Department of Physics, J adavpur University, Kolkatta, \\ India \\ ${ }^{3}$ Biochemical Sciences Division, CSIR-National Chemical \\ Laboratory, Pune, India \\ ${ }^{4}$ Animal House Facility, Regulatory Toxicology Group, \\ CSIR-Indian Institute of Toxicology Research, Lucknow, \\ India \\ ${ }^{5}$ Chromatography Unit, Analytical Chemistry \& Mass \\ Spectrometry Division, CSIR-Indian Institute of Chemical \\ Technology (CSIR-IICT), Hyderabad, India \\ \$These authors contributed equally to this work \\ *Correspondling author: Mohana Krishna Reddy \\ Mudiam, Chromatography Unit, Analytical Chemistry \\ \& Mass Spectrometry Division, CSIR-Indian Institute of \\ Chemical Technology (CSIR-IICT), Tarnaka, Uppal Road, \\ Hyderabad - 500 007, Telangana, India
}

Received: April 20, 2017; Accepted: May 18, 2017;

Published: May 25, 2017

\begin{abstract}
Titanium dioxide nanoparticle ( $\left.\mathrm{TiO}_{2} \mathrm{NP}\right)$ is one of the most commonly used engineered nanoparticles. It has attracted lot of interest to analytical toxicologists in recent past due to its toxicity on human health and environment. The present study was aimed to explore the GC-MS based metabolomics as a tool to investigate the toxicity of $\mathrm{TiO}_{2} \mathrm{NP}$ in comparison to $\mathrm{TiO}_{2} \mathrm{BP}$ with doses of 300 , $600,1200 \mathrm{mg} / \mathrm{kg}$ respectively in both gender(s) of Swiss Albino mice for 7 and 14 days. Serum biochemistry and histopathology parameters were performed. Chemometric analysis by supervised PLS-DA was performed to identify the discrimination/classification between exposed and non-exposed samples due to metabolic perturbations. The morphological, biochemical, haematological and metabolomic analysis revealed that, $\mathrm{TiO}_{2} \mathrm{NP}$ has induced toxicological effects to both female and male mice. The results showed that metabolomics along with biochemical analysis can be employed as a comprehensive tool to identify the toxicity of NPs in the model organisms at molecular level.
\end{abstract}

Keywords: Toxicity; Nanoparticles; Gas chromatography-Mass Spectrometry; Metabolomics

\section{Abbreviations}

GC-MS: Gas Chromatography-Mass Spectrometry; NP: Nano Particles; BP: Bulk Particles; $\mathrm{TiO}_{2}$ NP: Titanium Dioxide Nano Particles; $\mathrm{TiO}_{2} \mathrm{BP}$ : Titanium Dioxide Bulk Particles; PLS-DA: Partial Least Square Discriminant Analysis; NMR: Nuclear Magnetic Resonance; AMDIS: Automated Mass Spectral Deconvolution and Identification System; NIST: National Institute of Standards and Technology; MS: Mass Spectrometry

\section{Introduction}

Titanium dioxide nanoparticles $\left(\mathrm{TiO}_{2} \mathrm{NPs}\right)$, one of the most widely engineered nanoparticles has many industrial applications in the areas of cosmetics, drug delivery, pigment in paints, ceramics and pharmaceuticals $[1,2]$. Globally, $\mathrm{TiO}_{2} \mathrm{NPs}$ are abundantly produced and widely used because of their smaller size and larger surface area with high stability and anticorrosion properties. Nowadays, a large number of nanoparticles are entering into our environment due to their usage due to advances in nanotechnology, thus, causing concern as they have potential impacts on human and environmental health [3]. The conventional toxicological experiments has revealed that, $\mathrm{TiO}_{2}$ NPs can produce free radicals with strong oxidizing ability which thus induce oxidative stress and finally resulted in apoptotic cell death, fibrosis, DNA damage and pulmonary inflammation [4-6].

In recent years, metabolomics has been shown as a valuable tool to identify and quantify the global changes in small molecular weight metabolites (amino acids, organic acids, sugar, fatty acids etc.) of an intra-cellular system to therapeutic intervention or toxicant and diseases [7]. Thus, metabolomics is considered as a potential tool in functional genomics, disease diagnosis, toxicology and pharmacology research $[8,9]$. This approach has been successfully used in toxicological sciences to understand the mechanism of action and to identify the biochemical responses to toxicant exposure.

Nuclear magnetic resonance (NMR) and mass spectrometry (MS) are considered to be two complementary analytical platforms to study the metabolic responses in any organism $[10,11]$. The separation efficiency and identification potential of mass spectrometry based metabolomics have improved by coupling it with separation techniques like gas and liquid chromatography [12-15]. The gas chromatography-mass spectrometry (GC-MS) based metabolomics has various advantages over other hyphenated analytical techniques which include, high chromatographic resolution, analyte-specific detection and quantification as well as capability to identify unknowns made it a suitable tool for metabolomics in the fields of toxicity and biomarker discovery. Therefore, the study has been carried out to evaluate the molecular events following oral dose of nanosized and bulk sized $\mathrm{TiO}_{2}$ particles in Swiss Albino mice at three different doses 300,600 and $1200 \mathrm{mg} / \mathrm{kg}$ body weight for 7 and 14 days by using GC-MS combined with pattern recognition approaches. Serum biochemistry and haematology tests were also performed.
Austin J Anal Pharm Chem - Volume 4 Issue 2 - 2017 ISSN : 2381-8913 | www.austinpublishing group.com Mudiam et al. (C) All rights are reserved
Citation: Singh AK, Ratnasekhar Ch, Chaudhari BP, Singh D, Chattopadhyay BD, Mudiam MKR. Evaluating Metabolic Responses in Mice to Nanosized Titanium Dioxide Particles Using Gas Chromatography-Mass Spectrometry Based Metabolomics. Austin J Anal Pharm Chem. 2017; 4(2): 1085. 


\section{Materials and Methods}

\section{Chemicals and reagents}

All chemicals used were analytical grade. Methoxyamine hydrochloride, N-methyl-N-trimethylsilyl trifluoracetamide (MSTFA) and all standards were procured from Sigma- Aldrich (St. Lous, MO, USA). Methanol was obtained from Sigma Aldrich (St. Lous, MO, USA). The ultra-pure water was prepared by RiOsTM water purification system (Millipore, Billerica, MA, USA). IMECO ULTRA SONICS (Bombay, India) was used as sonicator. Heto GD-2 maxi dry plus (Germany) was used as lyophilizer.

\section{Particle characterization}

A stock solution of $1 \mathrm{mg} / \mathrm{ml}$ of $\mathrm{TiO}_{2} \mathrm{NP}$ in Milli-Q water was prepared and subjected to $15 \mathrm{~min}$ ultrasonic vibration (Sonics \& Material Inc.) for dispersion. Furthermore, the surface morphology of the $\mathrm{TiO}_{2} \mathrm{NP}$ was confirmed by using a scanning electron microscope (SEM with EDAX - Apollo XL, FEI, Eindhoven, Netherlands).

\section{Animal selection}

The present study was carried out on male and female Swiss Albino mice weighing $25-30 \mathrm{gm}$. The animals were housed in polypropylene cages with stainless steel grids under optimal conditions (humidity $50 \pm 10 \%$ ), temperature $22 \pm 3^{\circ} \mathrm{C}$ and light intensity 12 -h light/dark cycle). Animals were provided with fed water and standard pellet diet ad libitum. The study protocol was approved by institutional ethics committee at CSIR-IITR.

\section{Experiment design}

Adult female and male mice were divided into 13 groups ((six groups for 7 days, six groups for 14 days and one control groups). Each group consists of 5 male and 5 female animals. These groups were given 300,600 , and $1200 \mathrm{mg} / \mathrm{kg} \mathrm{TiO}{ }_{2} \mathrm{NP}$ and $\mathrm{TiO}_{2} \mathrm{BP}$ administered by a single oral gavage according to the Organization for Economic Co-operation and Development, 420 (OECD, 1992) to Swiss Albino female and male mice for 7 and 14 days. Body weight and clinical signs of toxicity were recorded throughout the period of experiment $[16,17]$.

\section{Sign of toxicity and mortality}

Signs of toxicity such as diarrhea and body weight loss were observed once daily throughout the experiment. After 7 and 14 days of dosing mice were sacrificed and blood was collected in $10 \%$ ethylene diamine tetra acetic acid (EDTA) anticoagulant containing tubes for hematology analysis and non-oxalate tubes for the separation of serum for metabolomic and biochemistry analysis.

\section{Clinical biochemistry}

The clinical biochemistry parameter of serum samples were carried out with fully automated biochemical analyzer (Clinical chemistry analyzer Randox-daytona UK) using standard kits. The following parameters were tested: glucose (GLU), creatinine (CREA), alanine aminotransferase (ALT), aspartate aminotransferase (AST), total protein (TP), triglycerides (TG), alkaline phosphate (ALP), uric acid (URCA) and cholesterol (CHOL).

\section{Hematological parameters}

Blood collected in 10\% EDTA was analyzed for white blood cells (WBC), red blood cells (RBC), hemoglobin (HGB), hematocrit
(HCT), mean cell volume (MCV), mean corpuscular hemoglobin $(\mathrm{MCH})$, mean corpuscular hemoglobin concentration (MCHC), platelet (PLT), neutrophils (NEUT) lymphocyte (LYM), monocyte (MONO), eosinophils (EO) and basophils (BASO) through automated cell counter Hematology analyzer (Sysmex XT-2000iV Analyzer-IDEX America) using standard kits.

\section{Metabolite extraction and derivatization}

Extraction of metabolites from serum and derivatization was implemented in a similar approach as previously described with little modifications [18]. Serum metabolites were extracted by adding $800 \mu \mathrm{l}$ of $\mathrm{MeOH}(80 \%, v / v)$ for deproteinization. After vortexing, samples were centrifuged at $10,000 \mathrm{rpm}$ for $15 \mathrm{~min}$. Then the extraction procedure with $80 \% \mathrm{MeOH}$ was repeated thrice and then all supernatants were pooled. The pooled extract was freeze dried using Scanvac system (Labogene, Denmark). To the resultant residue, an amount of $40 \mu \mathrm{l}$ of methoxyamine hydrochloride was added and mixed vigorously for $1 \mathrm{~min}$ and then incubated at $65^{\circ} \mathrm{C}$ for $30 \mathrm{~min}$. To this, $90 \mu \mathrm{l}$ of N-methyl- N-(trimethylsilyl)-trifluoroacetamide was added and incubated at $65^{\circ} \mathrm{C}$ for $1 \mathrm{hr}$ under agitation using a thermo mixer (BR BIOCHEM Life sciences, India). Samples were made up to the volume of $400 \mu \mathrm{l}$ using hexane for further analysis using GC-MS.

\section{GC-MS instrumentation and data acquisition}

The GC-MS analysis was performed for metabolomics as previously described in studies [19]. Metabolite profiling was performed on Trace GC ultra (Thermo Scientific, FL, USA) coupled to TSQ Quantum XLS mass spectrometer (Thermo Scientific, FL, USA). TG-5MS fused silica capillary column $(30 \mathrm{~m} \times 250 \mu \mathrm{m}$ i.d; Thermo Scientific), chemically bonded with 5\% phenyl $95 \%$ methyl polysiloxane cross linked stationary phase $(0.25 \mu \mathrm{m}$ film thickness) was utilized to separate the peaks. GC injector was used in split less mode. The injector temperature was set at $260^{\circ} \mathrm{C}$. Helium, the carrier gas, was maintained at a constant flow rate of $1.1 \mathrm{ml} / \mathrm{min}$ during the analysis. The column temperature was initially kept at $65^{\circ} \mathrm{C}$ for $2 \mathrm{~min}$, then ramped to $230^{\circ} \mathrm{C}$ at a rate of $6^{\circ} \mathrm{C} / \mathrm{min}$ and then finally increased to $290^{\circ} \mathrm{C}$ at a rate of $10^{\circ} \mathrm{C} / \mathrm{min}$, where it was held for $20 \mathrm{~min}$. The interface temperature and ion source were set at $290^{\circ} \mathrm{C}$ and $220^{\circ} \mathrm{C}$ respectively. Electron impact ionization $\left(\mathrm{EI}^{+}\right)$mode was used for mass detection with electron energy of $70 \mathrm{eV}$. Mass spectra were acquired with a scan range of $\mathrm{m} / \mathrm{z} 45-800$. Solvent delay was set at $7 \mathrm{~min}$. The sample volume of $1 \mu \mathrm{l}$ was injected in GC-MS for analysis [19].

\section{Data pre-processing}

Serum used for metabolomic analysis as a single batch in random order. AMDIS software (version 2.0) was used to identify the metabolites in serum. The mass spectra of all the detected compounds were compared with spectra in NIST library (version 2.0) or standards for confirmation. All GC-MS raw data files were exported into Net CDF format using XCalibur software (Thermo Fisher Scientific, FL, USA).

Deconvolution of the Net CDF format files was performed using the XCMS software [20]. The data was arranged on a three dimensional matrix consisting of arbitrary peak index (RT-m/z pair), sample names and peak area. The total area normalization was performed in order to reduce the systematic biases within the experiment. Normalized data was used for multivariate analysis to remove the offsets and adjust the importance of high and low 
Table 1: Morbidity and mortality in mice after orally administered $\mathrm{TiO}_{2} \mathrm{NPs}$.

\begin{tabular}{|c|c|c|c|c|c|}
\hline \multirow{2}{*}{$\begin{array}{c}\text { Dose }(\mathrm{mg} / \\
\mathrm{kg})\end{array}$} & \multicolumn{3}{|c|}{ Body weight $(\mathrm{g})$} & Total deaths & Signs of toxicity \\
\cline { 2 - 6 } & 0 days & 7 days & 14 days & & \\
\hline Female & \multicolumn{2}{|c|}{} & & Nil \\
\hline Control $(n=5)$ & $25.3 \pm 0.8$ & $27.3 \pm 0.8$ & $31.8 \pm 0.8$ & 0 & Nil \\
\hline $300(n=5)$ & $26.2 \pm 0.7$ & $28.3 \pm 0.7$ & $32.2 \pm 0.7$ & 0 & Nil \\
\hline $600(n=5)$ & $25.4 \pm 0.6$ & $27.5 \pm 0.6$ & $33.5 \pm 0.8$ & 0 & Diarrhea, weight \\
\hline $1200(n=5)$ & $27.6 \pm 0.7$ & $28.9 \pm 0.7$ & $26.2 \pm 0.9$ & 0 & loss \\
\hline Male & & & & & Nil \\
\hline Control $(n=5)$ & $25.8 \pm 0.8$ & $26.9 \pm 0.6$ & $32.8 \pm 0.7$ & 0 & Nil \\
\hline $300(n=5)$ & $25.7 \pm 0.9$ & $26.7 \pm 0.7$ & $33.2 \pm 0.9$ & 0 & Nil \\
\hline $600(n=5)$ & $26.6 \pm 0.7$ & $27.4 \pm 0.3$ & $33.5 \pm 0.6$ & 0 & Diarrhea, weight \\
\hline $1200(n=5)$ & $26.8 \pm 0.5$ & $28.6 \pm 0.6$ & $25.2 \pm 0.5$ & 0 & loss \\
\hline
\end{tabular}

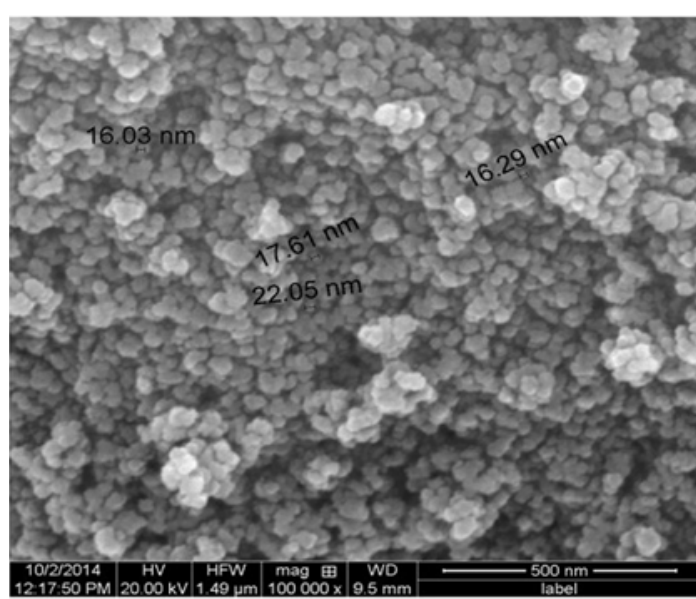

Figure 1: SEM image of $\mathrm{TiO}_{2} \mathrm{NP}(<25 \mathrm{~nm})$.

abundance metabolites to an equal level.

\section{Multivariate pattern recognition analysis}

Metabo Analyst tool was used for data processing and statistical analysis [21]. To identify the differential metabolites that account for the separation between groups, supervised PLS-DA was applied. PLS-DA model was validated using the leave one out cross validation method [22]. Quality of model is assessed on $\mathrm{R}^{2}$ and $\mathrm{Q}^{2}$ scores [23]. Further, model validation was performed by 500 times permutation tests [24]. Metabolites with variable importance in projection (VIP) values of greater than 1 were taken as potential marker metabolites.

\section{Results and Discussion \\ In-life parameters}

Oral administration of $\mathrm{TiO}_{2} \mathrm{NP}$ at 300 and $600 \mathrm{mg} / \mathrm{kg}$ did not produce any signs of toxicity and mortality during 7 and 14 days exposure in both male and female mice. However, there was significant reduction in body weight of animals at high dose $(1200 \mathrm{mg} / \mathrm{kg})$ at 14 days along with significant toxicity symptoms (Table 1).

\section{Characterization of $\mathrm{TiO}_{2} \mathrm{NPs}$}

Characterization of NPs is one of the critical factors responsible for nanoparticles property and their mechanism of cellular interaction. We also measure the average size of NPs by scanning electron microscope (SEM). It was ranged from 16.03 to $22.05 \mathrm{~nm}$ (Figure 1).

\section{Animal observation and body weight}

Adverse signs, symptoms and mortality were not observed after 7 and 14 days of oral treatment with 300,600 and $1200 \mathrm{mg} / \mathrm{kg} \mathrm{BW}$ of nanosized and bulk sized $\mathrm{TiO}_{2}$ particles in mice. However, mice treated with high dose $(1200 \mathrm{mg} / \mathrm{kg})$ of $\mathrm{TiO}_{2} \mathrm{NPs}$ showed some irritation, dullness and the significant reduction in feed intake, body weight gain.

\section{Clinical biochemistry}

The results of serum biochemical parameters of female and male mice after orally administered $\mathrm{TiO}_{2} \mathrm{NP}$ for 14 days were shown in Table 2. Serum biochemistry parameters such as Glucose, AST, ALT, triglycerides and alkaline phosphate were significantly changed in both female and male mice exposed to $\mathrm{TiO}_{2} \mathrm{NP}$ at high concentration $(1200 \mathrm{mg} / \mathrm{kg})$ dose as compared to controls for 14 days. No changes were observed in biochemistry parameters after exposure to

Table 2: Biochemical data of mice orally administered $\mathrm{TiO}_{2} \mathrm{NP}$ for 14 days.

\begin{tabular}{|c|c|c|c|c|c|c|c|}
\hline \multicolumn{8}{|c|}{$\mathrm{TiO}_{2} \mathrm{NP}(\mathrm{mg} / \mathrm{kg})$} \\
\hline \multirow[t]{2}{*}{ Parameters } & \multirow[t]{2}{*}{ Control } & 300 & 600 & 1200 & 300 & 600 & 1200 \\
\hline & & \multicolumn{3}{|c|}{ Female } & \multicolumn{3}{|c|}{ Male } \\
\hline GLU (mg/dL) & $120.47 \pm 7.51$ & $125.00 \pm 2.65$ & $127.67 \pm 6.12$ & $127.67 \pm 5.78$ & $129.67 \pm 4.48$ & $115.33 \pm 2.02$ & $105.33 \pm 1.85^{*}$ \\
\hline CREA (mg/dL) & $0.37 \pm 0.06$ & $0.40 \pm 0.06$ & $0.39 \pm 0.10$ & $0.38 \pm 0.03$ & $0.43 \pm 0.06$ & $0.48 \pm 0.15$ & $0.37 \pm 0.03$ \\
\hline AST $(\mu / L)$ & $176.00 \pm 23.26$ & $180.00 \pm 7.94$ & $198.33 \pm 9.21$ & $210.00 \pm 17.50$ & $251.33 \pm 12.57$ & $277.67 \pm 20.51$ & $298.67 \pm 9.83^{*}$ \\
\hline $\operatorname{ALT}(\mu / L)$ & $177.00 \pm 4.93$ & $182.33 \pm 16.22$ & $178.00 \pm 3.21$ & $164.10 \pm 0.95$ & $175.67 \pm 4.41$ & $190.33 \pm 3.67$ & $219.33 \pm 4.70^{*}$ \\
\hline $\mathrm{TP}(\mathrm{g} / \mathrm{dL})$ & $6.37 \pm 0.45$ & $4.27 \pm 0.09$ & $4.53 \pm 0.18$ & $5.03 \pm 0.22$ & $4.50 \pm 0.35$ & $5.20 \pm 0.04$ & $5.37 \pm 13.81$ \\
\hline $\mathrm{TG}(\mathrm{mg} / \mathrm{dL})$ & $50.67 \pm 2.60$ & $56.67 \pm 7.54$ & $54.00 \pm 6.51$ & $57.00 \pm 2.52$ & $53.63 \pm 0.35$ & $51.33 \pm 3.38$ & $44.33 \pm 5.69^{*}$ \\
\hline $\operatorname{ALP}(\mu / L)$ & $373.67 \pm 38.20$ & $345.67 \pm 6.74$ & $354.67 \pm 12.33$ & $354.67 \pm 0.33$ & $382.00 \pm 10.26$ & $409.67 \pm 46.96$ & $416.33 \pm 16.49 *$ \\
\hline URCA (mg/dL) & $1.37 \pm 0.15$ & $0.57 \pm 0.18$ & $0.50 \pm 0.15$ & $0.83 \pm 0.28$ & $1.43 \pm 0.18$ & $14.33 \pm 1.20$ & $5.77 \pm 4.11$ \\
\hline $\mathrm{CHOL}(\mathrm{mg} / \mathrm{dL})$ & $60.67 \pm 6.23$ & $61.67 \pm 0.33$ & $58.67 \pm 5.36$ & $55.33 \pm 1.76$ & $61.00 \pm 7.81$ & $58.67 \pm 3.38$ & $40.00 \pm 1.00$ \\
\hline GLU (mg/dL) & $120.47 \pm 7.51$ & $125.00 \pm 2.65$ & $127.67 \pm 6.12$ & $127.67 \pm 5.78$ & $129.67 \pm 4.48$ & $115.33 \pm 2.02$ & $105.33 \pm 1.85^{*}$ \\
\hline
\end{tabular}

${ }^{*}$ Significant at the level of $p<0.05$. 
Table 3: Hematology data of mice orally administered $\mathrm{TiO}_{2} \mathrm{NP}$ for 14 days.

\begin{tabular}{|c|c|c|c|c|c|c|c|}
\hline \multicolumn{8}{|c|}{$\mathrm{TiO}_{2} \mathrm{NP}(\mathrm{mg} / \mathrm{kg})$} \\
\hline \multirow[t]{2}{*}{ Parameters } & \multirow[t]{2}{*}{ Control } & 300 & 600 & 1200 & 300 & 600 & 1200 \\
\hline & & \multicolumn{3}{|c|}{ Female } & \multicolumn{3}{|c|}{ Male } \\
\hline WBC $\left(10^{3} / \mu \mathrm{L}\right)$ & $14.07 \pm 4.81$ & $17.04 \pm 0.76$ & $16.08 \pm 0.86$ & $15.02 \pm 0.91$ & $16.36 \pm 0.75$ & $19.99 \pm 3.71$ & $26.91 \pm 2.86$ \\
\hline $\mathrm{RBC}\left(10^{6} / \mu \mathrm{L}\right)$ & $5.93 \pm 0.45$ & $6.19 \pm 0.31$ & $5.17 \pm 0.45$ & $5.67 \pm 0.47$ & $5.64 \pm 0.52$ & $6.15 \pm 0.69$ & $6.46 \pm 0.64$ \\
\hline $\mathrm{Hb}(\mathrm{g} / \mathrm{dl})$ & $11.93 \pm 0.55$ & $10.80 \pm 1.51$ & $11.37 \pm 2.17$ & $13.33 \pm 0.88$ & $10.13 \pm 0.95$ & $13.20 \pm 0.80$ & $10.83 \pm 2.00$ \\
\hline НСТ (\%) & $37.97 \pm 1.55$ & $37.90 \pm 1.42$ & $32.70 \pm 3.08$ & $39.60 \pm 1.80$ & $31.67 \pm 3.01$ & $33.23 \pm 1.52$ & $29.20 \pm 5.90^{*}$ \\
\hline MCV (fl) & $64.50 \pm 4.22$ & $62.07 \pm 2.99$ & $67.47 \pm 4.21$ & $81.50 \pm 6.21$ & $62.93 \pm 0.44$ & $63.00 \pm 5.03$ & $57.50 \pm 1.12$ \\
\hline NEUT (\%) & $9.97 \pm 1.93$ & $10.00 \pm 2.98$ & $13.97 \pm 3.25$ & $14.87 \pm 4.79$ & $15.20 \pm 2.55$ & $14.67 \pm 2.35$ & $24.43 \pm 1.63^{\star}$ \\
\hline EO (\%) & $0.90 \pm 0.15$ & $1.17 \pm 1.82$ & $1.23 \pm 052$ & $1.97 \pm 0.32$ & $1.87 \pm 0.91$ & $1.90 \pm 2.41$ & $0.77 \pm 0.12$ \\
\hline BASO (\%) & $0.83 \pm 0.55$ & $0.67 \pm 0.33$ & $1.00 \pm 0.31$ & $0.80 \pm 0.40$ & $0.63 \pm 0.15$ & $0.30 \pm 0.10$ & $1.03 \pm 0.60^{*}$ \\
\hline LYM (\%) & $84.03 \pm 3.68$ & $64.77 \pm 1.34$ & $79.03 \pm 3.81$ & $68.77 \pm 8.10$ & $81.50 \pm 4.25$ & $61.73 \pm 12.09$ & $108.00 \pm 10.75^{*}$ \\
\hline MONO (\%) & $4.27 \pm 1.30$ & $5.07 \pm 0.75$ & $5.13 \pm 0.29$ & $4.07 \pm 0.39$ & $3.80 \pm 0.76$ & $3.40 \pm 0.64$ & $4.23 \pm 1.57$ \\
\hline
\end{tabular}

*Significant at the level of $p<0.05$

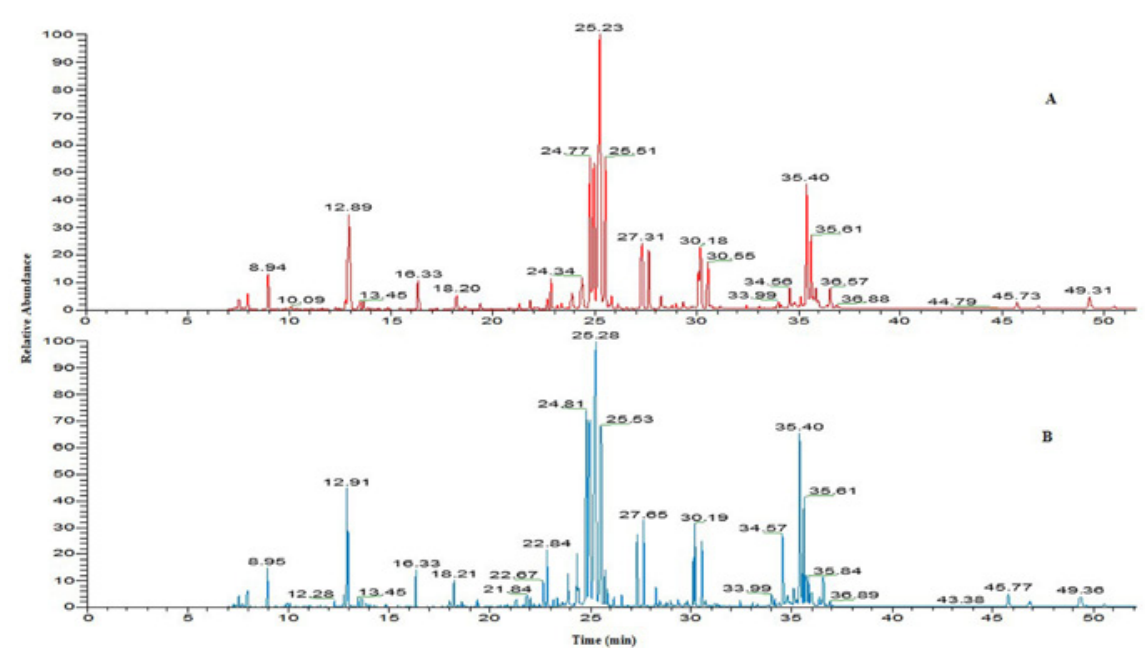

Figure 2: The total ion chromatogram of serum samples of (A) control; (B) $1200 \mathrm{mg} / \mathrm{kg} \mathrm{TiO} \mathrm{NP}_{2}$ exposed mice.

$\mathrm{TiO}_{2} \mathrm{NP}$ for 7 days. In the study, we found increased levels of serum enzymes AST, ALT and alkaline phosphatase in treated mice at high concentration $(1200 \mathrm{mg} / \mathrm{kg})$ of $\mathrm{TiO}_{2} \mathrm{NP}$ at 14 days. It is considered to be potential biomarker of liver damage. Therefore, our data suggest that liver damage might have occurred in mice due to exposure of $\mathrm{TiO}_{2}$ NPs.

\section{Haematological parameters}

There were no significant changes in haematological parameters in both gender orally administered to $\mathrm{TiO}_{2} \mathrm{NP}$ and $\mathrm{TiO}_{2} \mathrm{BP}$ $(300,600,1200 \mathrm{mg} / \mathrm{kg})$ for 7 days. However, a significant changes $(\mathrm{p}<0.05)$ were noted in WBC, HCT, NEUT and BASO in animals after exposed to $\mathrm{TiO}_{2} \mathrm{NP}(1200 \mathrm{mg} / \mathrm{kg})$ as compared to control for 14 days (Table 3). WBC, HCT, NEUT and BASO significant increased in $\mathrm{TiO}_{2} \mathrm{NP}$ treated mice at high dose $(1200 \mathrm{mg} / \mathrm{kg})$ for 14 days, suggesting that nanosized $\mathrm{TiO}_{2}$ particles may induce inflammation and it may also generate oxidative stress via activation of oxidative stress responsive transcription factors [25]. Therefore increased level of some haematology parameters like WBC resulting from administration of $\mathrm{TiO}_{2}$ NPs may induce oxidative stress. Earlier studies also reported that $\mathrm{TiO}_{2} \mathrm{NP}$ can produce free radicals which can exert a strong oxidizing ability and produce oxidative stress in rodents [26-29].

\section{Metabolic responses of mice after exposure to $\mathrm{TiO}_{2} \mathrm{NP}$}

All mice were survived in the experimental conditions and no mortality was found in treated group of mice after exposure for a period of 7 and 14 days. The results of metabolomic studies were carried out at three different doses 300, 600, $1200 \mathrm{mg} / \mathrm{kg} \mathrm{BW}$ of $\mathrm{TiO}_{2} \mathrm{NP}$ respectively. Figure 2 shows that a representative total ion chromatogram of serum of control and exposed mice at high concentration $(1200 \mathrm{mg} / \mathrm{kg})$ of $\mathrm{TiO}_{2} \mathrm{NP}$.

Multivariate analysis was performed to reduce the data to low dimensional space, where discrimination of metabolic profiles between sample classes can be modelled. Supervised PLS-DA was performed to find a small number of linear combinations of the original variables, which was predictive for the class membership and that, described most of the variability of the metabolic profiles of control and exposed samples. PLS-DA loadings plots were used to identify the metabolites that were responsible for the observed 

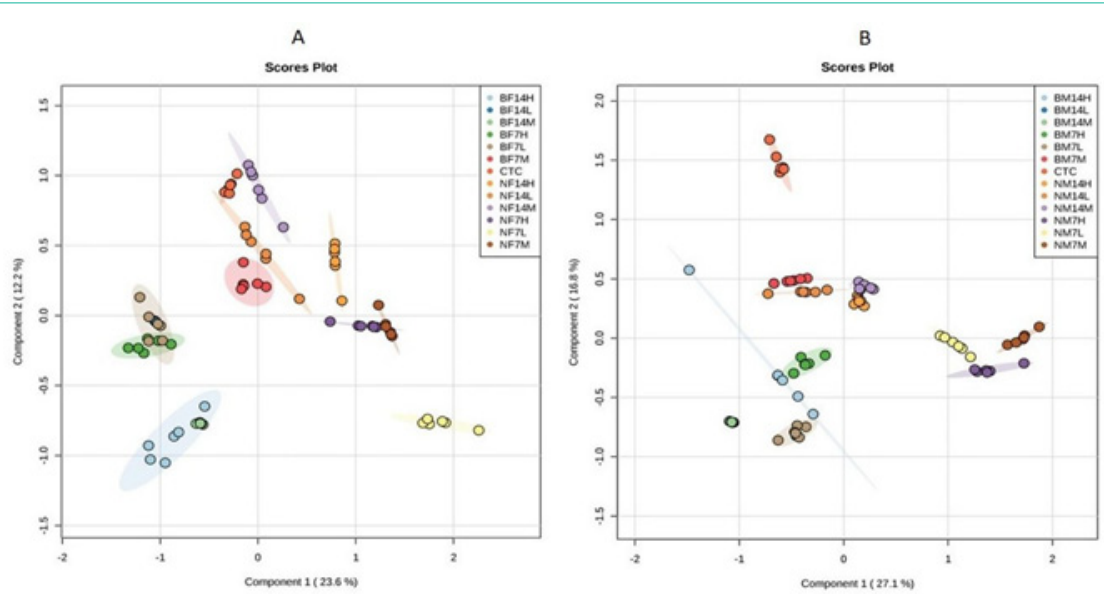

Figure 3: Partial least square discriminate analysis (PLS-DA) scores plot of first component Vs second component for (A) female mice; (B) male mice extracts showing the separation of control group, from $\mathrm{TiO}_{2} \mathrm{NP}$ and $\mathrm{TiO}_{2} \mathrm{BP}$ exposed mice for 7 and 14 days at concentration of $300 \mathrm{mg} / \mathrm{kg}$ (L; Low dose), $600 \mathrm{mg} / \mathrm{kg}$ (M; Medium dose), $1200 \mathrm{mg} / \mathrm{kg}$ (H; High dose). BF14; Bulk particle in female mice for 14 days, BF7; Bulk particle in female for 7 days, CTC; control, BM14; Bulk particle in male mice for 14 days, BM7; Bulk particle in male mice for 7 days, NF14; Nanoparticle in female mice for 14 days, NF7; Nanoparticle in female mice for 7 days, NM14; Nanoparticle in male mice for 14 days, NF7; Nanoparticle in male mice for 7 days.
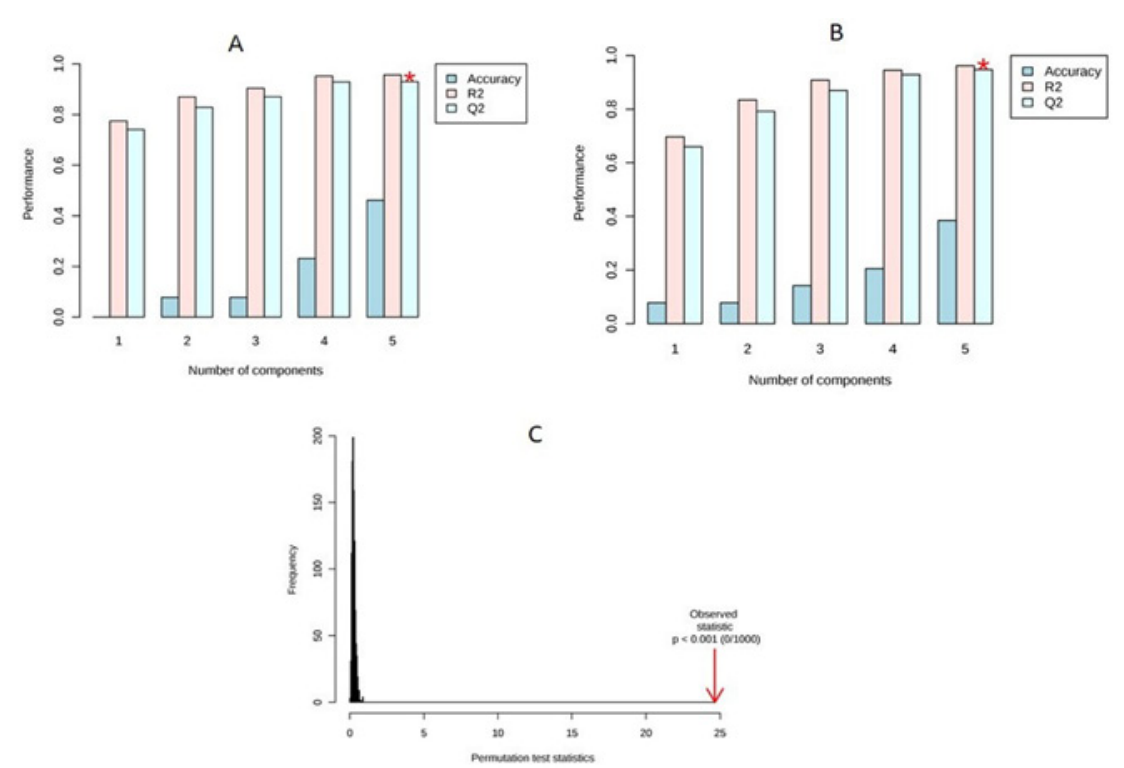

Figure 4: (A) Cross validation of female mice; (B) Cross validation of male mice; (C) Permutation analysis of PLS-DA models derived fromTiO ${ }_{2}$ exposed and controls of female and male mice.

separation between scores of the control and treated mice. The PLS-DA results were displayed as scores plots indicating scatter of samples, which indicate similar metabolomic compositions when clustered together and compositionally different metabolomic compositions when dispersed. In female mice, the supervised PLSDA model obtained from GC-MS analysis of the samples revealed that the general structure of the complete data set, in which two components cumulatively accounted for $35.8 \%$ of the total variance with Component 1 (C1) explained 23.6\% and Component 2 (C2) explained 12.2\% (Figure 3A).

In male mice, two components cumulatively accounted for $43.9 \%$ of the total variance with $\mathrm{C} 1$ explained $27.1 \%$ and $\mathrm{C} 2$ explained $16.8 \%$ of the total variance respectively (Figure $3 \mathrm{~B}$ ). In both male and female mice, clear clusters were identified in PLS-DA scores plot. PLS-DA scores plot showed that, there was significant separation $(\mathrm{p}<0.05)$ among control and $\mathrm{TiO}_{2} \mathrm{NP}$ and $\mathrm{TiO}_{2} \mathrm{BP}$ treated group of mice along first component. A clear, linear dose trend with separation becoming more obvious the greater the dose (Figure 3). According to obtained results from PLS-DA, it is clearly suggested that changes of metabolic responses in treated mice were concentration dependent.

Visual examination of PLS-DA score plots is not a reliable method for determining predictive power. Therefore internal cross validation was performed to find out the predictive accuracy and fit of the polynomial model. The cumulative values of PLS-DA model with $\mathrm{R}^{2} \mathrm{X}_{\text {cum }}=0.349, \mathrm{R}^{2} \mathrm{Y}_{\text {cum }}=0.431, \mathrm{Q}^{2} \mathrm{X}_{\text {cum }}=0.297, \mathrm{Q}^{2} \mathrm{Y}_{\text {cum }}=0.352$ shows good fit of the model in female mice (Figure $4 \mathrm{~A}$ ). The cumulative 
Table 4: Differential metabolites in female mice between $\mathrm{TiO}_{2} \mathrm{NP}$ exposed and control groups.

\begin{tabular}{|c|c|c|c|c|c|c|c|}
\hline S.No & CheBI ID & Name of metabolite & $\begin{array}{c}\mathrm{RT} \\
(\mathrm{min})\end{array}$ & $m / z$ & VIP score & $p$-value & $\begin{array}{c}\text { Content } \\
\text { variance }\end{array}$ \\
\hline 1 & CID:22600307 & Silanamine & 15.16 & 188 & 1.0218 & $5.10 \mathrm{E}-30$ & Decreased \\
\hline 2 & CHEBI:6650 & Malic acid & 17.92 & 245 & 1.3999 & 8.73E-34 & Increased \\
\hline 3 & CHEBI: 18183 & Pyroglutamic acid & 18.47 & 156 & 1.5802 & $9.20 \mathrm{E}-30$ & Decreased \\
\hline 4 & CHEBI:30915 & Ketoglutaric acid & 19.62 & 288 & 1.0597 & $1.03 \mathrm{E}-17$ & Decreased \\
\hline 5 & CHEBI:18257 & Ornithine & 22.81 & 174 & 1.6673 & $8.25 E-35$ & Increased \\
\hline 6 & CHEBI:30887 & Isocitric acid & 24.21 & 465 & 1.7452 & $1.27 \mathrm{E}-27$ & Increased \\
\hline 7 & CHEBI:28875 & Tetradecanoic acid & 24.30 & 285 & 1.7662 & 4.85E-26 & Increased \\
\hline 8 & CHEBI: 18186 & Tyrosine & 25.05 & 179 & 1.554 & $6.85 E-24$ & Increased \\
\hline 9 & CHEBI:28757 & Glucose & 25.36 & 217 & 1.054 & 2.01E-14 & Decreased \\
\hline 10 & CHEBI:59265 & Palmitelaidic acid & 27.14 & 311 & 1.5171 & $3.51 E-23$ & Decreased \\
\hline 12 & CHEBI:16196 & Oleic acid & 28.23 & 96 & 1.4572 & $1.74 \mathrm{E}-38$ & Increased \\
\hline 13 & CHEBI:28842 & Stearic acid & 28.69 & 298 & 1.7235 & $2.34 \mathrm{E}-57$ & Decreased \\
\hline 14 & CHEBI:32265 & Heptadecanoic acid & 28.99 & 327 & 1.0286 & $9.01 E-35$ & Decreased \\
\hline 15 & CHEBI:15843 & Arachidonic acid & 30.51 & 91 & 1.4786 & 3.87E-34 & Increased \\
\hline
\end{tabular}

Table 5: Differential metabolites in male mices between $\mathrm{TiO}_{2} \mathrm{NP}$ exposed and control groups.

\begin{tabular}{|c|c|c|c|c|c|c|c|}
\hline S.No & CheBI ID & Name of metabolite & $\begin{array}{c}\text { RT } \\
\text { (min) }\end{array}$ & $m / z$ & $\begin{array}{l}\text { VIP } \\
\text { score }\end{array}$ & $p$-value & $\begin{array}{c}\text { Content } \\
\text { variance }\end{array}$ \\
\hline 1 & CHEBI:28358 & Lactic acid & 8.46 & 190 & 1.2567 & $5.22 E-31$ & Increased \\
\hline 2 & CHEBI:20067 & 3-Hydroxybutyric acid & 10.65 & 130 & 1.4375 & 3.84E-39 & Decreased \\
\hline 3 & CHEBI:15428 & Glycine & 13.98 & 174 & 1.2489 & 4.23E-24 & Increased \\
\hline 4 & CHEBI:18012 & Fumaric acid & 14.76 & 245 & 1.4406 & 3.38E-37 & Increased \\
\hline 5 & CHEBI:17822 & Serine & 15.24 & 204 & 1.4898 & 7.98E-23 & Decreased \\
\hline 6 & CHEBI:22660 & Aspartic acid & 16.50 & 168 & 1.285 & $6.53 E-34$ & Decreased \\
\hline 7 & CHEBI:6650 & Malic acid & 17.92 & 245 & 1.0865 & $6.20 \mathrm{E}-31$ & Increased \\
\hline 8 & CHEBI: 18183 & Pyroglutamic acid & 18.47 & 156 & 1.7314 & 8.08E-46 & Decreased \\
\hline 9 & CHEBI:30915 & Ketoglutaric acid & 19.62 & 288 & 1.5741 & $1.22 \mathrm{E}-30$ & Decreased \\
\hline 10 & CHEMSPIDER: 10709816 & Phosphopyruvate & 19.91 & 211 & 2.0992 & 4.90E-38 & Increased \\
\hline 12 & CHEBI:18257 & Ornithine & 22.81 & 174 & 2.1934 & $2.52 \mathrm{E}-40$ & Increased \\
\hline 13 & CHEBI:30887 & Isocitric acid & 24.21 & 465 & 1.5379 & 7.77E-36 & Increased \\
\hline 14 & CHEBI:28875 & Tetradecanoic acid & 24.30 & 285 & 1.7954 & $1.52 \mathrm{E}-47$ & Increased \\
\hline 15 & CHEBI:59265 & Palmitelaidic acid & 25.05 & 179 & 1.4911 & $1.75 \mathrm{E}-30$ & Decreased \\
\hline 16 & CHEBI:33198 & Gluconic acid & 27.14 & 311 & 1.2888 & 8.59E-28 & Decreased \\
\hline 17 & HMDB41480 & Cis-13-octadecenoic acid & 30.04 & 339 & 1.6197 & $4.41 E-27$ & Decreased \\
\hline
\end{tabular}

values of PLS-DA model with $\mathrm{R}^{2} \mathrm{X}_{\text {cum }}=0.474, \mathrm{R}^{2} \mathrm{Y}_{\text {cum }}=0.674, \mathrm{Q}^{2} \mathrm{X}_{\text {cum }}$ $=0.388, \mathrm{Q}^{2} \mathrm{Y}_{\text {cum }}=0.599$ shows good fit of the model in male mice (Figure 4B). To assess the statistical significance of these apparently highly predictive multivariate models, permutation testing was conducted. The supervised models were further validated with 1000 times permutation tests $(\mathrm{p}<0.001)$ (Figure $4 \mathrm{C})$.

Among all the differential variables selected according to the VIP values from the PLS-DA model (VIP score greater than 1), 15 metabolites in female and 17 metabolites in male mice were found in treated group respectively showed in Table 4 and Table 5 . In present study, glucose levels were down regulated in serum of treated groups of $\mathrm{TiO}_{2} \mathrm{NP}$ in comparison to control. This down regulation in the level of glucose suggested being as results of increase in the energy requirements of mice exposed to $\mathrm{TiO}_{2} \mathrm{NP}$. These results showed that disturbance of energy metabolism after exposure to $\mathrm{TiO}_{2} \mathrm{NP}$ [30] .

We found, lactic, citric, malic and fumaric acids were significantly $(\mathrm{p}<0.05)$ increased in serum after exposed to $\mathrm{TiO}_{2} \mathrm{NPs}_{\text {in }}$ comparison to control group. Lactic acid acts as a precursor in Krebs cycle (TCA cycle). Citric, malic and fumaric acids were said to be key products in TCA cycle. Citric and lactic acids were closely related to glycolysis and 


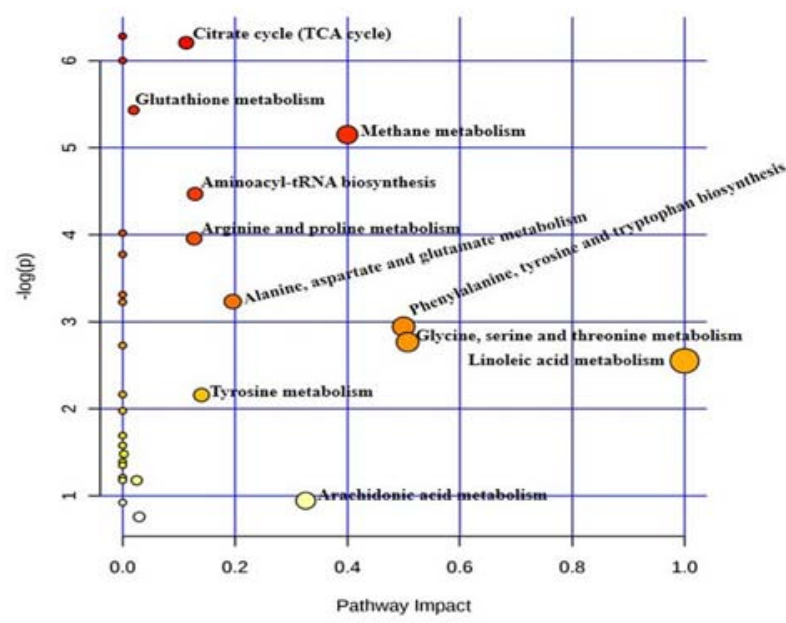

Figure 5: Summary of the pathway analysis of mice exposed to $\mathrm{TiO}_{2} \mathrm{NP}$ with MetPa.

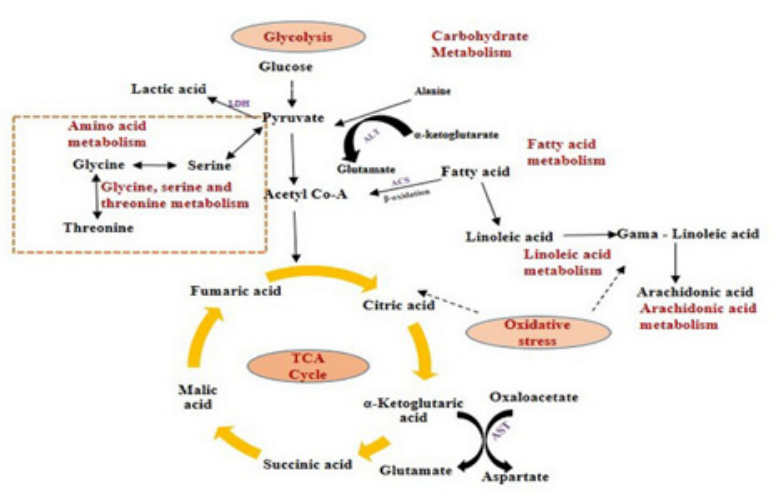

Figure 6: Schematic representation of the affected pathways in Swiss Albino mice due to $\mathrm{TiO}_{2} \mathrm{NP}$ exposure.

energy metabolic pathway in aerobic condition (Figure 6) [31]. The abnormality of citric and lactic acids may be due to induced oxidative stress in the mice due to $\mathrm{TiO}_{2} \mathrm{NPs}$, which indirectly causes metabolic perturbations in energy metabolism through glycolysis process.

In the study, the level of 3-hydroxybutyric acid was significantly $(\mathrm{p}<0.05)$ decreased in exposed mice after treatment of $\mathrm{TiO}_{2} \mathrm{NP}$. Our findings were supported by previous study where, 3-hydroxybutyric acid said to be an end product of fatty acid beta-oxidation pathway produced mainly in the liver and used as an alternative energy source during tissue damage.

The levels of tyrosine and glycine were significantly increased and the levels of serine and aspartic were significantly decreased in treated mice in comparison to control. Glycine is derived from serine with the help of serine hydroxymethyl transferase enzyme and it acts as a cytoprotective agent by scavenging the reactive oxygen species (ROS) and inhibits inflammatory response due to oxidative stress induced by the NPs. Increased serine levels in serum have been related to cellular proliferation and it may decline the cell injury caused by the reactive oxygen species (ROS).

The affected biological pathways in mice after exposure to $\mathrm{TiO}_{2} \mathrm{NP}$ were obtained by using MetPa, a free web-based tool [32].
MetPa reveals importantly, 14 metabolic pathways in mice which showed in Table 6 (Figure 5). Schematic representation of the affected pathways in Swiss Albino mice due to $\mathrm{TiO}_{2} \mathrm{NP}$ exposure showed in Figure 6. Fatty acids are important source of energy. In this study, tetradecanoic, arachidonic, oleic and linoleic acids were significantly increased while, palmitelaidic, stearic, heptadecanoic and cis-13octadecenoic acids were significantly decreased in serum after exposed to $\mathrm{TiO}_{2}$ NP. MetPA results showed two pathways related to fatty acid metabolism such as linoleic acid metabolism and arachidonic acid metabolism was significantly affected in treated mice. GC-MS based metabolomic approach can be used as a potential analytical tool to understand the systemic toxicity of NPs in model organisms [33-35].

\section{Conclusion}

In conclusion, this is the first comparative metabolomics study on both male and female mice using GC-MS based metabolomics approach to identify the perturbations in metabolic profile after exposed to $\mathrm{TiO}_{2} \mathrm{NP}$. Result of multivariate pattern recognition analysis showed clear molecular group responses to $\mathrm{TiO}_{2} \mathrm{NP}$ at metabolic level. The study revealed that the metabolic perturbations occurred in $\mathrm{TiO} 2 \mathrm{NP}$ exposed mice are both concentration and time dependent. The integrated data set indicated clear indication of oxidative stress 
Table 6: Affected pathways, metabolites hits and their impacts identified by MetPa in mice.

\begin{tabular}{|c|l|c|c|}
\hline S.No & \multicolumn{1}{|c|}{ Pathway } & Metabolite hits & Impact \\
\hline 1 & Citrate cycle (TCA cycle) & 3 & 0.1134 \\
\hline 2 & Glutathione metabolism & 3 & 0.02004 \\
\hline 3 & Methane metabolism & 2 & 0.4 \\
\hline 4 & Aminoacyl-tRNA biosynthesis & 3 & 0.12903 \\
\hline 5 & Arginine and proline metabolism & 2 & 0.12736 \\
\hline 6 & $\begin{array}{l}\text { Alanine, aspartate and glutamate } \\
\text { metabolism }\end{array}$ & 1 & 0.1962 \\
\hline 7 & $\begin{array}{l}\text { Phenylalanine, tyrosine and tryptophan } \\
\text { biosynthesis }\end{array}$ & 2 & 0.50732 \\
\hline 8 & Glycine, serine and threonine metabolism & 1 & 1 \\
\hline 9 & Linoleic acid metabolism & 2 & 0.14045 \\
\hline 10 & Tyrosine metabolism & 1 & 0.00233 \\
\hline 11 & Starch and sucrose metabolism & 1 & 0.02533 \\
\hline 12 & Cysteine and methionine metabolism & 1 & 0.32601 \\
\hline 13 & Arachidonic acid metabolism & & 0.02976 \\
\hline 14 & Primary bile acid biosynthesis & 1 & \\
\hline & & & 1 \\
\hline
\end{tabular}

and alteration of energy metabolism as a result of $\mathrm{TiO}_{2} \mathrm{NP}$ exposure. Moreover, our results support the fact that metabolomics approach is a more sensitive than serum biochemistry and haematology analysis. These results showed that metabolomics have a great potential to emerge as a powerful tool to comprehensively understand the toxicity of NPs in model organisms.

\section{Acknowledgment}

The authors are thankful to Directors of CSIR-IITR, Lucknow and CSIR-IICT, Hyderabad for scientific discussions and providing the necessary infrastructural facilities to carry out this work. The author(s) received financial support from SERB, New Delhi and CSIR, New Delhi through fast track scheme and NanoSHE (BSC0112) network projects to carry out this research work.

\section{References}

1. Hayauchi Y. Precise colour determination method for tablets - an application of instrumental colour measurement in the pharmaceutical development. Pharmeur Sci Notes. 2005; 1: 21-26.

2. Salthammer T, Fuhrmann F. Photocatalytic surface reactions on indoor wall paint. Environ. Sci. Technol. 2007; 41: 6573-6578.

3. Federici G, Shaw BJ, Handy RD. Toxicology of titanium dioxide nanoparticles to rainbow trout (Oncorhynchus mykiss): gill injury, oxidative stress, and other physiological effects. Aquat Toxicol. 2007; 84: 415-430.

4. Zhang DD, Hartsky MA, Warheit DB. Time course of quartz and TiO (2) particle-induced pulmonary inflammation and neutrophil apoptotic responses in rats. Exp Lung Re. 2002; 8: 641-670.

5. Rehn B, Seiler F, Rehn S, Bruch J, Maier M. Investigations on the inflammatory and genotoxic lung effects of two types of titanium dioxide: untreated and surface treated. Toxicol Appl Pharmacol. 2003; 189: 84-95.

6. Baan RA. Carcinogenic hazards from inhaled carbon black, titanium dioxide, and talc not containing asbestos or asbestiform fibers: recent evaluations by an IARC Monographs Working Group. Inhal Toxicol. 2007; 19: 213-218.

7. Ryan D, Robards K. Metabolomics: the greatest omics of them all? Anal chem. 2006; 78: 7954-7958.

8. Spratlin JL, Serkova NJ, Eckhardt SG. Clinical applications of Metabolomics in Oncology: a review. Clin Cancer Res. 2009; 15: 431-440.
9. Johnson $\mathrm{CH}$, Patterson AD, Idle JR, Gonzalez FJ. Xenobiotic Metabolomics: major impact on the Metabolome. Annu Rev Pharmacol and Toxicol. 2012; 52: 37-56.

10. Dettemer K, Aronov PA, Hammock BD. Mass spectrometry-based metabolomics. Mass Spectrum Rev. 2007; 1: 51-56.

11. Lindon JC, Nicholson JK, Holmes E, Everett JR. Metabonomics: metabolic process studied by NMR spectroscopy of biofluids. Concepts Magn Reson. 2006; 12: 289-320

12. Mudiam MK, Ch R, Saxena PN. Gas chromatography-mass spectrometry based metabolomic approach for optimization and toxicity evaluation of earthworm sub-lethal responses to carbofuran. PLoS One. 2008; 8: e81077.

13. Bujak R, Garcıa-Alvarez A, Ruperez FJ, Nuno-Ayala M, Garcıa, Ruiz- Cabello J. Metabolomics reveals metabolite changes in acute pulmonary metabolism. J Protome Res. 2014; 13: 805-816.

14. Hu ZP, Browne ER, Liu T, Angel TE, Ho PC, Chan EC. Metabolomic profiling of TASTPM transgenic Alzheimer's disease mouse model. J Proteome Res. 2012; 11: 5903-5913.

15. Koek MM, Jellema RH, Greef JVD, Tas AC, Hankemeier T. Quantitative metabolomics based on gas chromatography mass spectrometry: status and perspectives. Metabolomics. 2011; 7: 307-328.

16. OECD. OECD Guidelines for Testing of Chemicals. No 420: Acute Oral Toxicity-fixed Dose Method. Organisation for Economic Co-operation and Development. Paris. 2001.

17. Dasal V, Venugopal R, Reddy GA. Oral toxic exposure of titanium dioxide nanoparticles on serum biochemical changes in adult male Wistar rats. Nanomedicine. 2014; 2: 46-53.

18. Dunn WB, Broadhurst D, Begley P, Zelena E, Francis-McIntyre S, Anderson $\mathrm{N}$, et al. Procedures for large-scale metabolic profiling of serum and plasma using gas chromatography and liquid chromatography coupled to mass spectrometry. Nat Protoc. 2011; 6: 1060-1083.

19. Ch R, Sonane M, Satish A, Mudiam MK. Metabolomics reveals the perturbations in the metabolome of Caenorhabditis elegans exposed to titanium dioxide nanoparticles. Nanotoxicology. 2015; 9: 994-1004.

20. Tautenhahn R, Patti GJ, Rinehart D, Siuzdak G. XCMS Online: a web-based platform to process untargeted metabolomic data. Anal Chem. 2012; 84: 5035-5039.

21. Xia J, Psychogios N, Young N, Wishart DS. MetaboAnalyst: a web server for metabolomic data analysis and interpretation. Nucleic Acids Res. 2009; 37: W652-W660

22. Rubingh CM, Bijlsma S, Derks EP. Assessing the performance of statistical validation tools for megavariate metabolomics data. Metabolomics. 2006; 2 : 53-61.

23. Broadhurst DI, Kell DB. Statistical strategies for avoiding false discoveries in metabolomics and related experiments. Metabolomics. 2006; 2: 171-196.

24. Xuan J, Pan G, Qiu Y. Metabolomic profiling to identify potential serum biomarkers for schizophrenia and risperidone action. Proteome Res. 2011; 10: $5433-5444$

25. Dalton JS, Janes PA, Jones NG, Nicholson JA, Hallam KR, Allen GC Photocatalytic oxidation of NOx gases using $\mathrm{TiO}_{2}$ : a surface spectroscopic approach. Environmen Pollution. 2002; 120: 415-422.

26. Cho I, Park J, Kim Y. Oxidative degradation and toxicity reduction of trichloroethylene (TCE) in water using $\mathrm{TiO}_{2}$ /solar light: comparative study of $\mathrm{TiO}_{2}$ slurry and immobilized systems. Environ Sci Health A. 2005; 40: 10331044.

27. Warheit DB, Brock WJ, Lee KP, Webb TR, Reed KL. Comparative pulmonary toxicity inhalation and instillation studies with different $\mathrm{TiO}_{2}$ particle formulations: impact of surface treatments on particle toxicity. Toxicol Sci. 2005; 88: 514-524

28. Bermudez E, Mangum JB, Wong BA, Asgharian B, Hext PM, Warheit DB, et al. Pulmonary responses of mice, rats, and hamsters to subchronic inhalation of ultrafine titanium dioxide particles. Toxicol Sci. 2004; 77: 347-357. 
29. Gu N, Hu H, Guo Q, Jin S, Wang C, Oh Y, et al. Effects of oral administration of titanium dioxide fine-sized particles on plasma glucose in mice. Food Chem Toxicol. 2015; 86: 124-131.

30. Tang $\mathrm{M}$, Zhang $\mathrm{T}$, Xue $\mathrm{Y}$, Wang $\mathrm{S}$, Huang $\mathrm{M}$, Yang $\mathrm{Y}$, et al. Dose dependent in vivo metabolic characteristics of Titanium dioxide nanoparticles. Nanosci Nanotechnol. 2010; 10: 8575-8583.

31. Liu S, Xu L, Zhang T, Ren G, Yang Z. Oxidative stress and apoptosis induced by nanosized titanium dioxide in PC12 cells. Toxicology. 2010; 267: 172-177.

32. Xia J, Wishart DS. MetPa: a web based metabolomics tool for pathway analysis and visualization. Bioinformatics. 2010; 26: 2342-2344.
33. Griffin JL, Bollard ME. Metabonomics: it's potential as a tool in toxicology for safety assessment and data integration. Curr Drug Metab. 2004; 5: 389-398.

34. Coen M, Holmes E, Lindon JC, Nicholson JK. NMR-based metabolic profiling and metabonomic approaches to problems in molecular toxicology. Chem Res Toxicol. 2008; 21: 9-27.

35. Bollard ME, Stanley EG, Lindon JC, Nicholson JK, Holmes E. NMR-based metabonomic approaches for evaluating physiological influences on biofluid composition. NMR Biomed. 2005; 18: 143-162.
Austin J Anal Pharm Chem - Volume 4 Issue 2 - 2017

ISSN : 2381-8913 | www.austinpublishing group.com

Mudiam et al. () All rights are reserved
Citation: Singh AK, Ratnasekhar Ch, Chaudhari BP, Singh D, Chattopadhyay BD, Mudiam MKR. Evaluating Metabolic Responses in Mice to Nanosized Titanium Dioxide Particles Using Gas Chromatography-Mass Spectrometry Based Metabolomics. Austin J Anal Pharm Chem. 2017; 4(2): 1085 